DOI 10.14746/ssp.2018.2.2

Marta BALCEREK-KoSIARZ ${ }^{1}$

Uniwersytet im. Adama Mickiewicza w Poznaniu

\title{
Działalność gospodarcza samorządu gminnego w RFN
}

Streszczenie: Brak środków finansowych na realizację zadań publicznych przekazanych w ustawach, wysokie raty spłaty zadłużenia, spadające zyski z inwestycji, wzrastające wydatki na personel administracyjny, brak polityki generowania przychodów, decyzje państwa federalnego oraz krajów związkowych o podatkach oraz ograniczenie publicznego zadłużenia doprowadziły do poszukiwania innych źródeł finansowania potrzeb członków wspólnot lokalnych. Jednym z nich jest prowadzenie przez samorząd terytorialny działalności gospodarczej. W artykule przedstawiono następujące zagadnienia: podstawy prawne działalności gospodarczej, pojęcie działalności gospodarczej, zakres jej wykonywania oraz formy organizacyjno-prawne, za pomoca których jednostki samorządu terytorialnego prowadzą działalność gospodarczą.

Słowa kluczowe: samorząd gminny w Niemczech, działalność gospodarcza samorządu gminnego, gospodarka komunalna

\section{Podstawy prawne dzialalności gospodarczej}

D ziałalność gospodarcza wynika z ustroju samorządu terytorialnego. Podstawy prawne prowadzenia działalności gospodarczej w Niemczech zostały uregulowane w ustawie zasadniczej, ustawach federalnych, konstytucjach krajów związkowych oraz w ustawach o samorządzie gminnym, oraz w gminnych ustawach budżetowych (Gemeindeordnungshaushalt). W ustawie zasadniczej podstawą są: art. 28 ust. 2, art. 109 ust. 2 i ust. 3, art. 110 ust. 1. Art. 28 ust. 2 (BGBl. S. 1.) chroni gminę w prowadzeniu działalności gospodarczej wskazując, że ,działalność gospodarcza w zakresie produkcji, oferowania, dzielenia się dobrami, usługami albo porównywalnymi usługami może prowadzić do uzyskania zysku” lub, które ,ze względu na określony cel publiczny mogą być do-

1 Projekt został sfinansowany ze środków Narodowego Centrum Nauki przyznanych na podstawie decyzji numer DEC-2012/07/N/HS5/01705. 
starczone" (Nierhaus, 2010, s. 37). W art. 109 ust. 2 i ust. 3 zaznaczono z kolei, że gminy jako część krajów związkowych muszą przestrzegać określonych ustaw krajów związkowych w sprawie budżetu. Natomiast w art. 110 ust. 1 zapisano, że działalność gospodarcza jest formą działalności państwa. Do podstaw prawnych prowadzenia działalności gospodarczej przez jednostki samorządu terytorialnego w krajach związkowych zalicza się:

- § 102-108 ustawy z dnia 24 lipca 2000 r. o samorzqdzie gminnym w Badenii-Wirtembergii (Gb1. 582);

- art. 86-99 ustawy z dnia 22 sierpnia 1998 r. o samorzadzie gminnym w Bawarii (GVB1. 796);

- $§ 100-110$ ustawy z dnia 10 października 2001 r. o samorzqdzie gminnym $w$ Brandenburgii (GVB1, I, 154);

- § 123-127a ustawy z dnia 7 marca 2005 r. o samorzadzie gminnym w Hesji (GVOB1. I, 142);

- §68-77 ustawy z dnia 8 czerwca 2004 r. o samorzadzie gminnym w Meklemburgii-Pomorzu Przednim (GVOB1. M-V, 205);

- § 107-109 ustawy z dnia 22 sierpnia 1996 r. o samorzqdzie gminnym w Dolnej Saksonii (GVB1. 382);

- § 107-118 ustawy z dnia 14 lipca 1994 r. o samorzqdzie gminnym w Nadrenii Pótnocnej-Westfalii (GV 666);

- § 85-92 ustawy z dnia 31 stycznia 1994 r. o samorzqdzie gminnym w Nadrenii-Palatynacie (GVB1.153);

- § 108-118 ustawy z dnia 27 czerwca 1997 r. o samorzqdzie gminnym w Kraju Saary (Amtsbl. 682);

- §90a-102 ustawy z dnia 18 marca 2003 r. o samorzqdzie gminnym w Saksonii (GVB1.55, 159);

- § 116-123 ustawy z dnia 5 października 2003 r. o samorzqdzie gminnym w Saksonii-Anhlat (GVB1. 568);

- § 101-109 ustawy z dnia 28 lutego 2003 r. o samorzqdzie gminnym w Szlezwiku-Holsztynie (GVOB1. 57);

- § 71-78 ustawy z dnia 28 stycznia 2003 r. o samorzqdzie gminnym w Turyngii (GVB1.41).

Oprócz tego działalność gospodarcza gmin obejmuje również przepisy krajów związkowych, które konstytuują ich samodzielność finansową, czyli samodzielność przychodów (Einnahmehoheit) i strat (Abgabehoheit).

Podstawą działalności gospodarczej jednostek samorządu terytorialnego w Niemczech jest zasada pomocniczości, która oznacza, że dopiero po wyczerpaniu wszystkich środków i narzędzi do realizacji zadań wła- 
snych przez gminę, można ją rozpocząć. Istnieje zastrzeżenie, że samorządy gminne nie mogą angażować się w takie przedsięwzięcia, w których wystapiłaby kolizja interesów z przedsiębiorcami prywatnymi.

Termin działalność gospodarcza, mimo powszechnego używania nie jest traktowany jednolicie. Pojęcie to wywodzi się z nauk ekonomicznych i nie znajduje odpowiedniego oparcia $w$ przepisach prawa. Prowadzi to do jego różnych interpretacji. Na gruncie niemieckiej literatury prawnej i ekonomicznej występuje spór o kryteria jego wyróżnienia (Otto, 2001, s. 221). Definicję działalności gospodarczej w Niemczech po raz pierwszy zawarto w ustawie z dnia 14 lipca 1994 r. o samorzqdzie gminnym Nadrenii Pótnocnej-Westfalii, w której wskazano, że „,działalność gospodarcza polega na powołaniu form organizacyjno-prawnych, które występują na rynku jako producent, oferent lub pośrednik dóbr i usług o ile zdolność tą będzie można wykazać również przed podmiotami prywatnymi nastawionymi na zysk" (GV. NW. S. 270). W definicji tej wskazano, że jednostki samorządu terytorialnego mogą tylko wtedy prowadzić działalność gospodarczą, gdy będą działały w obrocie rynkowym na takich samych warunkach jak podmioty prywatne w znamiennych dla nich formach organizacyjno-prawnych (Erichsen, 1987, s. 10). Z kolei w ujęciu przedmiotowym działalność gospodarcza to także „całość wszystkich rzeczowych, finansowych i personalnych narzędzi gminy w celu zaspokojenia potrzeb jej mieszkańców" (Gern, 2003, s. 399). Wynika z tego, instrumentalne traktowanie działalności gospodarczej jako sposobu realizacji zadań gminy. Jest ono zatem wyrazem aktywności w sferze publicznej i prywatnej, czyli gospodarką przychodów i strat.

W niemieckiej nauce o samorządzie nie stworzono odrębnej definicji działalności gospodarczej korporacji publicznoprawnych. Podstawowym kryterium jej wyróżnienia jest zysk. Na jego podstawie oddziela się działalność w sferze publicznej (nienastawionej na zysk) od rynkowej (nastawionej na zysk).

W celu rozpoczęcia działalności gospodarczej muszą być łącznie spełnione 3 warunki, które wywodzą się z czasów niemieckiej ustawy gminnej z 1935 r. Warunki te stanowią podstawę do rozdzielania działalności gospodarczej (rynkowej, nastawionej na zysk) od działalności niegospodarczej (publicznej, nienastawionej na zysk) (RGB1. I S. 49). Każda z ustaw samorządowych w krajach związkowych inaczej uregulowała kwestię tego podziału. Tylko w: Bawarii, Brandenburgii, SaksoniiAnhalcie oraz Turyngii wprowadzono rozróżnienie na działalność gospodarczą i niegospodarczą (Nierhaus, 2011, s. 37). Warunki te obejmują: 
- realizację celu publicznego przez gminy;

- dostosowanie formy działalności gospodarczej do potrzeb lokalnych oraz zdolności gminy do ich zaspokojenia;

- zachowanie zasady subsydiarności (Schmidt, 2013, s. 204).

Warunki te nie zostały wprowadzone do wszystkich ustaw samorządowych po drugiej wojnie światowej. Największe kontrowersje w tym względzie budził cel publiczny. W Kraju Saary, Saksonii-Anhalcie, Brandenburgii wskazano, że działalność nastawiona na zysk nie realizuje celu publicznego. Natomiast w Nadrenii Północnej-Westfalii ustawa przewiduje, że działalność gospodarcza może go urzeczywistnić (Nierhaus, 2011, s. 38). O ile drugi warunek nie budzi większych wątpliwości, o tyle trzeci z nich inaczej rozpatrywano niż obecnie. Po drugiej wojnie światowej subsydiarność rozumiano w wąskim ujęciu. Polegała ona na tym, że gmina mogła tyko wtedy prowadzić działalność gospodarczą, gdy żaden inny podmiot publiczny lub prywatny nie był w stanie zrealizować zadania publicznego (czyli dostarczyć dóbr lub usług komunalnych) na odpowiednim poziomie. Oznaczało to, że gmina nie miała wówczas konkurencji w zaspokajaniu potrzeb lokalnych. Rozwiązanie to przetrwało z powodzeniem tylko w: Brandenburgii, Meklemburgii-Pomorzu Przednim, Saksonii i Szlezwiku-Holsztynie.

Zdaniem Michaela Nierhausa warunki z ustawy z 1935 r. uległy przeobrażeniu. Trzy kwestie doprowadziły do zmiany podejścia w nauce o samorządzie:

- klauzula eksterytorialności;

- kwalifikowana zasada subsydiarności (zaprzeczenie zasady subsydiarności w wąskim ujęciu);

- zmniejszenie ochrony zasobów przedsiębiorstw (spółek) komunalnych.

Klauzula eksterytorialności dotyczy prowadzenia działalności gospodarczej jednostek samorządu terytorialnego poza granicami gminy, w celu zaspokojenia potrzeb członków wspólnoty samorządowej. Jest dopuszczalna tylko wtedy, gdy gmina nie jest w stanie ich zrealizować na swoim obszarze. Zasada ta występuje w większości krajów związkowych z wyjątkiem Dolnej Saksonii, Nadrenii-Palatynatu oraz Saksonii. Z kolei w ujęciu kwalifikowanym subsydiarność oznacza, że gmina nie może wykonać usług publicznych, jeżeli lepiej realizuje je podmiot prywatny. Tylko w Bawarii wprowadzono dodatkowe obowiązki gmin w tym wymiarze. Zalicza się do nich: prowadzenie badań rynkowych $\mathrm{z}$ zakresu usług komunalnych oraz utrzymywanie dialogu z przedsiębior- 
cami (GVB1 1998, S. 796.). Tymczasem zmniejszenie ochrony zasobów przedsiębiorstw komunalnych związane jest z kwestią ponoszenia odpowiedzialności za działalność w obrocie rynkowym taką, jaką mają przedsiębiorcy. Jeżeli forma organizacyjno-prawna, powołana do wykonania zadań publicznych, nie jest w stanie ich spełnić i popadnie w tym zakresie w długi można przeciw niej rozpocząć postępowanie egzekucyjne z mienia samorządowego. Inaczej wygląda procedura w przypadku wykonywania zadań zleconych, którą inicjuje kraj związkowy. Prawo do wszczęcia egzekucji ma wówczas powiat, ale tylko w odniesieniu do spraw, w których gmina była organem właściwym do ich wykonania, a powiat ponosił za nie odpowiedzialność (Richter, 2006, s. 754).

Zakres prowadzenia działalności gospodarczej samorządu gminnego obejmuje wykonywanie zarówno zadań własnych, jak i zleconych. Działalność gospodarczą w Niemczech gmina może realizować przez:

- zawarcie umowy;

- bezpośrednią działalność;

- formy organizacyjno-prawne.

Niemiecki samorząd gminny posiada status przedsiębiorcy. Warunkiem nabycia tego statusu jest działalność w odpowiedniej formie organizacyjnej w obrocie cywilnoprawnym. Działalność gospodarcza może ponadto podlegać licznym ograniczeniom. Przykładowo gmina ma prawo jednorazowo podjąć działalność gospodarczą w sytuacji, gdy przekazano jej nowe zadanie do wykonania lub kiedy ma miejsce całkowita zmiana sposobu jego realizacji (Öbbecke, 2011, s. 65). Ograniczenia mogą również dotyczyć zakazu wykonywania określonych zadań np. tworzenia i prowadzenia instytucji bankowych z wyłączeniem kas oszczędnościowych.

Podsumowując, zakres wykonywania działalności gospodarczej wyznacza kryterium opłacalności podjętych działań, czyli zysk. W niemieckim piśmiennictwie uwaga koncentruje się na tym, czy prowadzić działalność zarobkową czy niezarobkową w zakresie świadczenia usług komunalnych. W Niemczech działalność gospodarcza skupia się na gospodarowaniu, czyli na administracji świadczącej. Musi być nastawiona na zysk i realizację celu publicznego. Charakter działalności gospodarczej nie przesądza o wyborze formy organizacyjno-prawnej jej prowadzenia w sferze publicznej i poza nią. Uczestnictwo samorządu w obrocie gospodarczym ma charakter szczególny, ponieważ produkty takiej działalności trafiają na rynek lokalny i są skierowane do konkretnego odbiorcy (ibidem, s. 62). 
Analizując zakres działalności gospodarczej w RFN należy następnie omówić jej wykonywanie w zakresie zadań występujących w sferze użyteczności publicznej i poza nią. Posłuży to do wskazania, które zadania najlepiej realizuje administracja władcza, a które świadcząca.

Samorząd gminny w RFN wykonuje swoje zadania w sferze użyteczności publicznej (Daseinsvorsorge) i poza tą sferą. Po raz pierwszy pojęcie użyteczności publicznej wyjaśnił Ernst Fortshoff w 1938 r. w publikacji Die Verwaltung als Leistungsträger. Wyprowadził je z pojęcia przywłaszczenia (apropriacji). Jednostka, aby zaspokoić swoje potrzeby niezbędne do tego, aby przetrwać, musi przywłaszczać sobie dobra innych osób. To, co jest niezbędne do przeżycia, powinno podlegać ochronie, aby nie doszło do odebrania niezbędnych dóbr innym osobom (Fortshoff, 1938). Stąd też, za Fortshoffem, użyteczność publiczna rozumiana jest jako dostarczanie usług, na które członkowie wspólnoty samorządowej są skazani (Simon, 2009, s. 19). Są to usługi gospodarcze i niegospodarcze, których przekazanie leży w interesie państwa (Dohms, 2001, s. 41).

Użyteczność publiczną można również definiować przez pryzmat podmiotów wykonujących te zadania. Działalność podmiotów komunalnych w tym zakresie obejmuje 3 obszary użyteczności publicznej. Pierwszy dotyczy dóbr publicznych, czyli urządzeń użyteczności publicznej i świadczonych za ich pomocą usług. Jego cechą charakterystyczną jest to, że podmioty spełniające te usługi nie czerpią $\mathrm{z}$ tego tytułu żadnych korzyści w przeciwieństwie do podmiotów korzystających z nich. Drugi obszar wynika z zawodności rynku w sytuacji dostarczania dóbr, efektów zewnętrznych i zjawiska korzyści skali. Stanowi on uzasadnienie działania organów władzy publicznej, które ponoszą za to odpowiedzialność. Natomiast trzeci obszar dotyczy działalności gospodarczej powiązanej z interesem publicznym. Korzyści z działalności ponoszą zarówno podmioty świadczące usługi, jak i korzystające z nich (Kożuch, KołoszkoChomentowska, 2003, s. 65).

Na podstawie analizy podmiotów komunalnych można postawić pytanie, kiedy mają one prawo przystąpić do obrotu gospodarczego, aby realizować zadania ze sfery użyteczności publicznej? W Niemczech podstawą w tym zakresie jest kryterium zysku. Każda forma aktywności podporządkowana jest opłacalności, czyli korzyściom, jakie przyniesienie w wykonaniu zadania (Kluth, 2011, s. 23). Ponadto gmina powinna również podjąć działalność gospodarczą z następujących powodów: skorygowania zawodności rynku w celu polepszenia realizacji usług komunalnych, zwiększenia wpływów do budżetu oraz braku środków finansowych na 
realizację zadań publicznych. W Niemczech działalność gospodarcza w sferze użyteczności publicznej musi realizować cel publiczny tożsamy z interesem publicznym, który polega na nieprzerywanym zaspokajaniu potrzeb (Wendt, 2011, s. 76).

Punktem wyjścia do analizy działalności gospodarczej w sferze użyteczności publicznej są dwa założenia: po pierwsze w ustawach można nakazać realizację określonego zadania w drodze działalności gospodarczej. Po drugie, rada gminy może zdecydować w uchwale o wyborze określonego sposobu realizacji, jeżeli ustawa tego nie wskazuje.

Zakwalifikowanie zadań do sfery użyteczności publicznej w Niemczech rodzi wiele problemów. W Bawarii, Brandenburgii, SaksoniiAnhalcie oraz Turyngii wyszczególniono zadania ze sfery użyteczności publicznej, które można wykonać w sferze gospodarczej. W pozostałych krajach związkowych wskazano tylko to, co należy do tej sfery i nie może podlegać pod działalność gospodarczą. Mowa w tym względzie o:

- zadaniach własnych obowiązkowych (Pflichtaufgaben);

- oświacie (szkołach, placówkach oświatowych);

- kulturze (bibliotekach, muzeach, teatrach, uniwersytetach);

- instytucjach integracyjnych i pobytu stałego (domach spotkań, pobytu dziennego, klubach, schroniskach dla bezdomnych, domach pomocy społecznej, domach starców);

- służbie zdrowia, sporcie i wypoczynku (szpitalach, placach gier, placach zabaw, parkach publicznych, boiskach sportowych, stadionach, otwartych i krytych pływalniach) (Püttner, 1993, s. 127);

- wywozie śmieci (Miemiec, 2012, s. 485).

To, co nie znajduje się w tym zakresie może być przedmiotem działalności gospodarczej.

Przedmiotem działalności gospodarczej w sferze użyteczności publicznej jest zatem infrastruktura techniczna (gospodarcza) i usługi społeczne. Infrastruktura techniczna to urządzenia i instytucje stwarzające podstawę do funkcjonowania gospodarki i warunków życia ludności. Do właściwości infrastruktury zalicza się: usługowy charakter, niepodzielność techniczną urządzeń, długowieczność, wysoką kapitałochłonność cyklu inwestycyjnego, trwały związek z terenem, wysoki udział kosztów, nierównomierność i nieelastyczność popytu i korzyści zewnętrzne. Z kolei usługi społeczne obejmują służbę zdrowia, opiekę społeczną, szkolnictwo, kulturę, rekreację i gospodarkę mieszkaniową. Należy w tym zakresie również wspomnieć, że z obowiązku wykonywania zadań o charakterze użyteczności publicznej wynika kompetencja do określenia 
wysokości cen, opłat, taryf za usługi komunalne, a także za korzystanie z obiektów i urządzeń użyteczności publicznej.

Z działalnością gospodarczą w sferze użyteczności publicznej związane są określone wady i zalety. Zagrożeniem o mniejszej dolegliwości związanym $\mathrm{z}$ aktywnością gospodarczą $\mathrm{w}$ tej przestrzeni jest dyktowanie warunków podmiotom prywatnym, w jaki sposób mają spełniać zadania publiczne. Wśród przeciwników prowadzenia działalności gospodarczej w sferze użyteczności publicznej podkreśla się również skutki wynikające z wykorzystywania statusu władzy publicznej do przyznania gminnym osobom prawnym pozycji uprzywilejowanej w stosunku do podmiotów prywatnych świadczących te same usługi publiczne. Sytuacja ta może doprowadzić nie tylko do dyskryminacji na rynku lokalnym konkurentów działających w oparciu o majątek prywatny, ale także do ich wyparcia i w efekcie do monopolu naturalnego (Skoczny, 1991, s. 6). To, co stanowi wady działalności w sferze użyteczności publicznej można przedstawić również jako jej zaletę. Monopol naturalny ma uzasadnienie wtedy, gdy samorządy gminne dążą do obniżenia kosztów społecznych wynikających z procesów technologicznym służących realizacji potrzeb członków wspólnoty samorządowej. Z drugiej strony ma rację bytu także wówczas, kiedy nie jest uzasadnione istnienie kilku producentów, a dzięki temu, że działa jeden świadczeniodawca (gmina) członek wspólnoty samorządowej otrzymuje dobro lub usługę po najniższych kosztach, niż gdyby miał wybrać jej realizację z szeregu ofert rynkowych. Wśród zalet prowadzenia działalności gospodarczej w sferze użyteczności publicznej należy także wymienić: wyższą efektywność w ich realizacji, większy zasięg aktywności na rynku lokalnym, co bezpośrednio przełoży się na rozwój gospodarczy i społeczny członków wspólnoty samorządowej (Zaborniak, 2004, s. 84).

Z przetoczonej analizy można wyciągnąć następujące wnioski, że samorządy gminne nie mają pełnej swobody wyboru formy organizacyjnoprawnych do realizacji swoich zadań w sferze użyteczności publicznej. $\mathrm{W}$ ich interesie powinno dojść do ujednolicenia formy zaopatrzenia w gaz, wodę i prąd. Przemawiają za tym nie tylko względy racjonalności i gospodarności, ale także uproszczenie trybu pracy oraz zmniejszenie kosztów związanych z ich działalnością. W niemieckiej nauce o samorządzie postuluje się wprowadzenie form prywatnoprawnych w postaci spółek prawa handlowych do realizacji zadań z zakresu użyteczności publicznej. Występuje powiązanie formy organizacyjno-prawnej ze specyfiką branży usług komunalnych, wielkością przedsiębiorstwa oraz programem roz- 
woju sfery usług samorządu gminnego. Dzięki obecności konkretnej wizji rozwoju sfery użyteczności publicznej powstało strategiczne podejście do przekształceń w sferze usług lokalnych i ich restrukturyzacji.

W RFN przyczyną prowadzenia działalności wykraczającej poza sferę użyteczności publicznej jest przede wszystkim brak środków finansowych na realizację zadań publicznych przekazanych w ustawach jednostkom samorządu terytorialnego. Organy administracji państwowej zostały zmuszone do poszukiwania źródeł innych niż te, które przekazuje państwo do wykonania powierzonych im obowiązków.

Dwa elementy składają się na działalność poza sferą użyteczności publicznej w RFN nastawienie na zysk oraz ryzyko związane z jej podjęciem. Pojęcie działalności gospodarczej wykraczającej poza sferę użyteczności publicznej polega zatem na działalności podejmowanej w celu podwyższenia dochodów budżetu gminy. Jest to wówczas działalność gospodarcza i dochodowa. O skali działalności gospodarczej poza sferą użyteczności publicznej przesądzają przepisy określające źródła dochodów jednostek samorządu terytorialnego. Jej zakres zawsze powinien służyć zaspokajaniu zbiorowych potrzeb wspólnoty lokalnej (Niewiadomski, 1998, s. 143-144).

W celu określenia istoty działalności gospodarczej poza sferą użyteczności publicznej należy najpierw rozpatrzyć jej koncepcje. W literaturze przedmiotu występują trzy modele prowadzenia działalności gospodarczej poza sferą użyteczności publicznej: model angielski, austriacki i niemiecki. Pierwszy z nich zakazuje całkowitego prowadzenia tego rodzaju działalności. Wynika to z miejsca samorządu terytorialnego w zdekoncentrowanej administracji państwowej. Zwolennicy tego modelu przedstawiają trzy argumenty w obronie tego stanowiska. Po pierwsze, z działalnością rynkową związane jest ryzyko upadłości jednostek samorządu terytorialnego. Po drugie, istnieje zagrożenie, że zadania z zakresu użyteczności publicznej nie zostałyby wykonane, ponieważ nie przynoszą żadnego zysku. Po trzecie, uprzywilejowana pozycja jednostek samorządu terytorialnego skutkuje ich lepszym i szybszym dostępem do informacji oraz możliwością zwolnienia swoich form organizacyjno-prawnych z podatków. Argumenty te w literaturze przedmiotu przetaczane są także jako uzasadnienie do rezygnacji z prowadzenia działalności gospodarczej w sferze użyteczności publicznej (Kożuch, Kołoszko-Chomentowska, 2003, s. 67).

Z kolei model austriacki dopuszcza w pełnym zakresie prowadzenie działalności gospodarczej. Głównie dlatego, że prowadzi ona do uzyska- 
nia dodatkowych środków, co szczególnie ważne jest w przypadku gmin o słabej kondycji finansowej. W modelu tym nie ma ustawowych ograniczeń i zakazów odnośnie jej zakresu. Oznacza to, że jednostki samorządu terytorialnego z powodzeniem realizują zadania ze sfery użyteczności publicznej i podejmują również działania poza tą sfera, w celu polepszenia swojej sytuacji budżetowej.

Tymczasem model niemiecki łączy w sobie dwie omówione koncepcje. Dopuszcza prowadzenie działalności gospodarczej nastawionej na zysk, ale tylko w ograniczonym zakresie.

W Niemczech działalność gospodarcza poza sferą użyteczności publicznej, nie musi być nastawiona na realizację celu publicznego. Można wyróżnić trzy sytuacje, w których gmina może rozszerzyć działalność w sferze użyteczności publicznej i poza nią. Obejmuje ona następujące przypadki:

- przedsięwzięcie jest uzasadnione celem publicznym;

- przedsięwzięcie pozostaje w stosownej relacji do zdolności świadczącej gminy oraz do przewidywanego zapotrzebowania;

- świadczenie to nie będzie lepiej realizowane przez żaden podmiot prywatny (Scholl, 2000, s. 6).

Ponadto do dodatkowych wymogów związanych z działalnością poza sferą użyteczności publicznej należą również: zapewnienie przez samorząd gminny bezpieczeństwa i higieny pracy, spraw sanitarnych, nadzoru budowlanego, dozoru technicznego, ochrony środowiska oraz o regulacji z zakresu policji administracyjnej. Działalność ta podlega zatem pod nadzór jednostek państwowych taki sam jak dla podmiotów prywatnych (Hidien, 1984, s. 98).

W Niemczech zakres wykonywania działalności gospodarczej wywołał problem związany z tym, czy pozostawić zadania w gestii gminy czy przekazać je podmiotom prywatnym. Tylko w dwóch krajach związkowych - Hesji i Kraju Saary - stawia się pytanie na ile i w jakim stopniu sprywatyzować komunalne spółki prawa handlowego. Wynika to z tego, że w Kraju Saary gminom nie wolno prowadzić działalności gospodarczej (Öbbecke, 2011, s. 65).

Porównując działalność gospodarczą w sferze użyteczności publicznej i poza nią pierwsza z nich jest istotniejsza, ponieważ zaspokaja potrzeby członków wspólnoty samorządowej. Ponadto jej dominujący charakter wynika również z jej rozbudowanego ujęcia w przepisach ustaw o samorządzie gminnym. Koncentracja na działalności jednostek samorządu terytorialnego $\mathrm{w}$ obrocie rynkowym prowadzi nieuchronnie do prywa- 
tyzacji zadań publicznych, a w konsekwencji również do prywatyzacji składników mienia i zmiany sposobów rozporządzania nimi, a mianowicie przejścia od administrowania do zarządzania. Zakres działalności gospodarczej poza sferą użyteczności jest szeroki, ponieważ nie musi prowadzić do realizacji celu publicznego, ale go nie wyklucza. Gminy w RFN mają ograniczone kompetencje w zakresie banków. Nie mogą ich założyć, przejąć ani nimi zarządzać. Mają prawo jedynie wykupu ich akcji, które moga ją czynić większościowym akcjonariuszem. Mimo ograniczeń ustawowych w zakresie bankowości, jednostki samorządu terytorialnego mogą tworzyć sieci komunalnych kas oszczędnościowych. Kasy oszczędnościowe to publicznoprawne formy organizacyjno-prawne. Do ich głównych zadań należy wspieranie i rozwój mienia lokalnego. Zadanie to realizowane jest przez udzielanie kredytów gminie, członkom wspólnoty lokalnej lub związkom międzygminnym (Schmidt, 2013, s. 212).

Podsumowując, nie da się sprowadzić różnic w zakresie działalności gospodarczej tylko do dwóch obszarów: charakteru (użyteczności publicznej) i motywów (powszechnego i bieżącego zaspokojenia potrzeb wspólnoty samorządowej). Podział na działalność w sferze użyteczności publicznej i poza nią nie zależy od tego, czy wykonywane zadania realizują cel publiczny zawarty w ustawach. Rozbudowana literatura na ten temat wskazuje, że częściej wybiera się działalność gospodarczą do wykonania zadań oraz kształtowania w jej wyniku warunków dla rozwoju przedsiębiorców na terenie gmin. Motywy podejmowanej działalności wiążą się w pierwszej kolejności z wykonaniem zadań publicznych, a dopiero w sytuacji braku środków z aktywnością komercyjną w celu ich realizacji.

Wybór sposobu wykonywania zadań publicznych stanowi element polityki jednostek samorządu terytorialnego. Moga je wykonywać za pośrednictwem form organizacyjno-prawnych lub zawierając umowy z innymi podmiotami. Problem form organizacyjno-prawnych w RFN jest inaczej przedstawiany w naukach prawnych i ekonomicznych. W niemieckiej literaturze prawniczej wskazuje się, że podstawą jest analiza regulacji ustawowych odnośnie funkcjonowania form organizacyjno-prawnych. Drugorzędne znaczenie odgrywa natomiast zysk i podniesienie konkurencyjności obszaru gminy (Kluth, 2011, s. 10). W naukach ekonomicznych jest odwrotnie. Na pierwszym miejscu znajduje się kwestia konkurencyjności i przedsiębiorczości w jednostkach samorządu terytorialnego oraz strategie zarządzania nimi. W związku z tym analiza form organizacyjno-prawnych koncentruje się na znalezieniu odpowiedzi na 
następujące pytanie: według jakich kryteriów należałoby wybrać formę organizacyjno-prawną?

W Niemczech na podstawie art. 28 ust. 2 (BGBl. S. 1.) przysługuje jednostkom samorządu gminnego samodzielność organizacyjna (Organisationshochheit) oraz prawo do samodzielnego wyboru formy organizacyjno-prawnej, w ramach której będą one prowadzić działalność gospodarczą, o ile przepisy prawne jej nie wskazują. Podstawą ich wyboru są cele publiczne i wymagania stawiane formie organizacyjno-prawnej w trakcie ich realizacji (Gern, 2002, s. 445). Kwestie te reguluje praktyka wskazując na te, które najlepiej sprawdzają się w przypadku realizacji określonych kompetencji gmin (Stober, 1992, s. 243).

W Niemczech jednostki samorządu gminnego mogą wykonywać swoje zadania w formach publicznoprawnych i prywatnoprawnych. Do form publicznoprawnych zalicza się:

- związki kierowane (Regiebetriebe);

- związki własne (Eigenbetriebe);

- kasy oszczędnościowe (Schmidt, 2013, s. 212).

Z kolei formy prywatnoprawne obejmują:

- jednoosobowe spółki kapitałowe jednostek samorządu terytorialnego;

- spółki z ograniczoną odpowiedzialnością;

- spółki akcyjne;

- spółki komandytowe;

- spółki komandytowo-akcyjne;

- spółdzielnie z ograniczoną odpowiedzialnością;

- banki (Schmidt, 2013, s. 212).

Samorządy gminne mają prawo do udziału w spółkach:

- jako akcjonariusz w spółce akcyjnej;

- jako wspólnik w spółce z ograniczoną odpowiedzialnością;

- jako akcjonariusz w spółce komandytowo-akcyjnej;

- jako komandytariusz w spółce komandytowej;

- w spółdzielni z ograniczoną odpowiedzialnością (tylko w RFN).

W Niemczech gminy nie mogą przystąpić ani w sferze użyteczności publicznej, ani poza nią do:

- spółek osobowych;

- spółek cywilnych;

- spółek komandytowych oraz spółek komandytowo-akcyjnych jako komplementariusz;

- spółdzielni z nieograniczoną odpowiedzialnością (Pitschas, Schoppa, 2011, s. 217). 
Rozważaniom na temat form organizacyjno-prawnych, w ramach których można wykonywać działalność gospodarczą, towarzyszą z reguły obawy przed prywatyzacją zadań publicznych samorządu. Warto zastanowić się, gdzie leży ich źródło. Otóż geneza tych poglądów sięga pierwszej połowy lat 50. ubiegłego wieku. Rozpoczął się wówczas proces przekształcania form publicznoprawnych w prywatnoprawne. W każdym kraju związkowym inaczej ten proces przebiegał. W Bawarii pozostało najwięcej form publicznoprawnych z przewaga zakładów własnych. W Nadrenii Północnej-Westfalii podwoiła się z kolei liczba jednoosobowych spółek prawa handlowego, które występowały albo jako spółki z ograniczoną odpowiedzialnością, albo spółki akcyjne. Przekształcenia w formy prywatnoprawne wywołały ostrą krytykę pośród zwolenników wykonywania zadań publicznych przez administrację władczą. Obawiano się prywatyzacji zadań publicznych oraz zarządzania sferą usług publicznych w sposób znamienny dla przedsiębiorców (Kluth, 2011, s. 6). Przełom w sporze pomiędzy zwolennikami podejścia opartego na wykonywaniu wszystkich zadań publicznych przez jednostki organizacyjne samorządu gminnego a zwolennikami ich przekazania podmiotom prywatnym przyszedł w latach dziewięćdziesiątych XX wieku. Od tego czasu zaczęto analizować formy działalności gospodarczej jednostek samorządu terytorialnego pod kątem ich odpowiedzialności za wykonane zadania. Wskutek podjętych analiz wprowadzono do ustaw samorządowych krajów związkowych pierwszeństwo wyboru form publicznoprawnych. Regulacje te zawierają: $\S 87$ ust. 1 ustawy o samorządzie gminnym w Nadrenii-Palatynacie, $\S 108$ ust. 1 ustawy o samorządzie gminnym Nadrenii Północnej-Westfalii, art. 92 ust. 1 ustawy o samorządzie gminnym Bawarii oraz $\S 96$ ust. 1 ustawy o samorządzie gminnym w Saksonii (Röger, 2005, s. 130). Dopiero w sytuacji, kiedy formy publicznoprawne okazałyby się nieskuteczne można było wybrać organizację prywatnoprawną. Stąd też w niemieckiej doktrynie prawa administracyjnego przedstawia się kryteria prywatnoprawnych form organizacyjnych, do których zalicza się następujące kwestie:

- na ile forma prywatnoprawna jest $\mathrm{w}$ stanie wykonać zadanie publiczne;

- na ile struktura organizacyjna zapewni sprawne wykonanie zadania;

- czy koszt wykonania zadania będzie pochodził z budżetu formy prywatnoprawnej czy z dotacji od jednostki samorządu terytorialnego;

- czy personel posiada odpowiednie kwalifikacje do wykonania zadania; 
- jaki jest zakres odpowiedzialności za realizowane zadania;

- czy przedsiębiorstwo będzie zwolnione z podatków za prowadzoną działalność;

- jaki rodzaj spółki jest najlepszy do wykonania zadania;

- jaki jest wpływ jednostki samorządu terytorialnego na spółkę;

- w jaki sposób zostaną unormowane stosunki między daną formą organizacyjno-prawną a mieszkańcami i innymi podmiotami prawnymi w zakresie świadczenia usług komunalnych (Pitschas, Schoppa, 2011, s. 111).

Rozważając kryteria wyboru form organizacyjno-prawnych nasuwa się w związku z tym pytanie o to: $\mathrm{w}$ jaki sposób stwierdzić czy powyższe kryteria przyczynią się faktycznie do podniesienia efektywności wykonywanych zadań? W tym celu w niemieckiej literaturze przedmiotu wyodrębnia się dwa kryteria:

- elastyczność i szybkość;

- koszty.

Pierwsze kryterium obejmuje rozwiązania w zakresie założenia, działania i rozwiązania przedsiębiorstwa. Im prostszy sposób jego utworzenia, tym szybszy jest sposób realizacji zadań. W nauce o samorządzie w RFN podkreśla się, że ustawy szczególne powinny regulować typy form organizacyjno-prawnych. Zgodnie z takim założeniem, jeżeli ich brakuje to należałoby rozpocząć inicjatywę ustawodawczą, która powinna zakończyć się przyjęciem odpowiedniego aktu normatywnego. Przykładowo kasy oszczędnościowe posiadają w każdym kraju związkowym swoją odrębną regulację prawną.

Elastyczność oznacza również samodzielność organów przedsiębiorstwa do zajmowania się daną sprawą. Odnosi się także do struktury organizacyjnej danej spółki, w której nie ma układu hierarchicznego. W przeciwieństwie do publicznoprawnych form reaguje ona szybciej na zmieniające się warunki rynkowe, a proces decyzyjny nie jest tak długi. Kryterium elastyczności i szybkości mają tylko wtedy znaczenie, gdy należy w krótkiej perspektywie czasowej wykonać jakieś zadania publiczne lub zrealizować określony projekt, obejmujący spełnienie potrzeb członków wspólnoty samorządowej nieprzewidzianych w ustawie.

W ramach elastyczności rozpatruje się także kwestie: oddziaływania, zarządzania i kontroli nad spółką kapitałową jednostki samorządu terytorialnego. Przedsiębiorstwa gminne, głównie w formie jednoosobowych spółek mają tendencję do uzależniania się od polityki gminy. Zgodnie z zasadą demokratycznego państwa prawa (Demokratiepriznip) wpływ 
pośredni na spółkę mają mieszkańcy za pośrednictwem organów samorządu gminnego wyłonionych w wyborach powszechnych. Inaczej jest w przypadku form prywatnoprawnych, wobec których jednostki samorządu terytorialnego nie sprawują kontroli lub robią to w ograniczonym zakresie.

Drugim kryterium są koszty. Utworzenie spółki z ograniczoną odpowiedzialnością lub spółki akcyjnej generuje określone wydatki. Nie ma ich w przypadku podmiotów publicznoprawnych (Pitschas, Schoppa, 2011, s. 117).

Podsumowując, niemiecki samorząd gminny znajduje się w fazie ewolucji sposobów prowadzenia działalności gospodarczej. Starania gmin idą w kierunku znalezienia pośredniej drogi pomiędzy rozwiązaniami rynkowymi a administracyjnymi. Coraz bardziej podkreśla się rolę partycypacji członków wspólnot lokalnych w zarządzaniu publicznym i włączeniu ich $\mathrm{w}$ proces decydowania o sposobach wykonywania zadań własnych i zleconych. Do tej pory nie powstały jeszcze modele łączące partycypację z zarządzaniem, czyli gospodarowaniem, a nie administrowaniem sprawami publicznymi.

\section{Bibliografia}

Dohms R. (2001), Die Vorstellung der Komissionen zur Daseinversorge, w: Daseinversorge im Lichte des Wettbewerbs, red. J. Schwarze, Baden-Baden.

Erichsen H.-U. (1987), Gemeinde und Private im wirtschaftlichen Wettbewerb, Heildelberg.

Forsthoff E. (1938), Die Verwaltung als Leistungsträger, Stuttgart.

Gern A. (2003), Deutsches Kommunalrecht, Baden-Baden.

Hidien J. W. (1984), Staatliche Wirtschaftaufsicht und Besteuerung kommunaler Unternehmen, w: Handbuch der kommunalen Wissenschaft und Praxis. Kommunale Wirtschaft, red. G. Püttner, t. 5, Berlin.

Kluth W. (2011), Kommunalwirtschaftliche Aktivitäten als Dienste von allgemeinen wirtschaftlichen Interesse, w: Handbuch der kommunalen Wissenschaft und Praxis. Kommunale Wirtschaft, red. T. Mann, G. Püttner, t. 2, Heildelberg.

Kożuch A., Kołoszko-Chomentowska Z. (2003), Działalność gospodarcza organizacji publicznych, Białystok.

Miemiec M. (2012), Prywatyzacja materialnych ustug komunalnych w Republice Federalnej Niemiec, w: Prawne aspekty prywatyzacji, red. J. Blicharz, Wrocław.

Niewiadomski Z. (1998), Samorzqd terytorialny w warunkach wspótczesnego państwa kapitalistycznego, Warszawa. 
Nierhaus M. (2011), Selbstverwaltungsgarantie und wirtschaftliche Betätigung der Kommunen, w: Handbuch der kommunalen Wissenschaft und Praxis. Kommunale Wirtschaft, red. T. Mann, G. Püttner, t. 2, wyd. 3, Heildelberg.

Otto C. (2001), Die Grenzen gemeindlicher Wirtschaftsbetätigung, Herbolzheim.

Öbbecke J. (2011), Kommunalrechtliche Voraussetzungen der wirtschaftlichen Betätigung, w: Handbuch der kommunalen Wissenschaft und Praxis. Kommunale Wirtschaft, red. T. Mann, G. Püttner, t. 2, Heildelberg.

Pitschas R., Schoppa K. (2011), Kriterien für die Wahl der Rechtsform, w: Handbuch der kommunalen Wissenschaft und Praxis. Kommunale Wirtschaft, red. T. Mann, G. Püttner, t. 2, Heildelberg.

Püttner G. (1993), Kommunalrecht Baden-Württemberg, Stuttgart.

Richter D. (2006), Kommunales Vermögen und seine Verwaltung, w: Recht der Kommunalfinanzen, red. H.-G. Hennecke, H. Pünder, C. Waldohoff, München.

Röger B. (2005), Insolvenz Kommunaler Unternehmen in Privatrechtsform. Am Beispiell kommunaler Eigengesellschaften in Nordrhein-Westfalen, Baden-Baden.

Schmidt T. I. (2013), Kommunalrecht, wyd. 3, München.

Scholl M. (2000), Die Kommune als Unternehmer - Rechtliche Voraussetzungen - Eine Synopse, „Kommunalpolitik”, nr 15.

Simon S. (2009), Liberalisierung von Dienstleistungen der Daseinversorge im WTOund EU-Recht, Tübingen.

Skoczny T. (1991), Dopuszczalność działalności gospodarczej gmin, „Samorząd Terytorialny", $\mathrm{nr} 3$.

Stober R. (1992), Kommunalrecht in der Bundesrepublik Deutschland, Stuttgart-Berlin-Köln.

Wendt R. (2011), Rechtschutz gegen wirtschaftliche Betätigung der Gemeinden, w: Handbuch der kommunalen Wissenschaft und Praxis. Kommunale Wirtschaft, red. T. Mann, G. Püttner, t. 2, wyd. 3, Heildelberg.

Zaborniak P. (2004), Granice działalności gospodarczej podmiotów komunalnych, Przemyśl.

Grundgesetz für die Bundesrepublik Deutschland v. 23. Mai 1949, BGB1. S. 1.

Deutsche Gemeindeordnung vom 30.1.1935, RGB1. I, S. 49.

Gemeindeordnung Rheinland-Pfalz v. 31. Januar 1994, GVB1.153, ze zm.; G. v. 6. Mai 2005, GVB1. 98.

Gemeindeordnung Nordrhein-Westfalen v. 14. Juli 1994 GV 666, ze zm.; G. v. 16. November 2004, GV 646.

Gemeindeordnung Saarland v. 27. Juni 1997, Amtsbl. 682, ze zm.; G. v. 8. Oktober 2003, Amtsbl. 2004, 594.

Gemeindeordnung Niedersachsen v. 22. August 1996 GVB1. 382; ze zm.; G. v. 13. Oktober 2005, GVB1. 316.

Gemeindeordnung Bayern z dnia 22 sierpnia 1998 r., GVB1 1998, S. 796. 
Gemeindeordnung Baden-Württemberg v. 24. Juli 2000 Gb1. 582, ber. 698, ze zm.; G. v. 28. Juli 2005; GB1 579.

Gemeindeordnung Brandenburg v. 10. Oktober 2001, GVB1, I, 154 ze zm.; G. v. 22. Juni 2005, GVB1, I, 210.

Gemeindeordnung Thüringen v. 28. Januar 2003, GVB1. 41 ze zm.; G. v. 25. November 2004, GBV1 857.

Gemeindeordnung Schleswig-Holstein v. 28. Februar 2003, GVOB1. 57 ze zm.; G. v. 1. Februar 2005, GVOB1. 58, 66.

Gemeindeordnung Sachsen v. 18. März 2003 GVB1.55, 159 ze zm.; G. v. 11. Mai 2005, GVB1. 155.

Kommunalverfassung für das Land Mecklenburg-Vorpommern v. 8. Juni 2004, GVOB1. M-V, 205.

Gemeindeordnung Sachsen-Anhalt v. 5. Oktober 2003, GVB1. 568 ze zm.; G. v. 22. Dezember 2004, GVB1 856.

Gemeindeordnung Hessen v. 7. März 2005, GVOB1. I, 142 ze zm.; G. v. 26. Juli 2004, GVOB1, 272.

\section{Economic activity of municipal local government in Germany}

\section{Summary}

The lack of financial resources for the fulfillment of public tasks laid down in legal acts, high loan payments, falling investment profits, increasing administrative expenses, the lack of policy aimed at generating revenue, tax decisions taken by federal and regional bodies, and the reduction of public debt have all led to local governments seeking new sources of financing. One such source could be the economic activity undertaken by local governments in Germany. In this paper the following issues are presented: the legal basis of economic activity, the definition of legal activity, the scope of economic activity and legal and organizational forms of economic activity of local governments.

Key words: local government in Germany, economic activity of local government, municipal economy 
